\title{
Perlindungan Lingkungan dalam Hukum Humaniter
}

\author{
Sri Wartini
}

\begin{abstract}
War has never been kind to human environment and human health. Trough out history, warfare has been associated with death, disease, pollution and destruction of the environment. The Human Rights Law and Humanitarian Law does not protect the Environment directly, so that the protection of those is still weak.
\end{abstract}

\section{Pendahuluan}

Perang dalam sejarah perkembangan .Imat manusia selalu berkonotasi dengan penderitaan, terutama bagi pihak yang kalah. Selain itu jika dihubungkan dengan lingkungan, perang juga mengakibatkan jencemaran dan kerusakan lingkungan. Sejarah telah membuktikan bahwa perang menimbulkan penderitaan bagi umat manusia dan kerusakan lingkungan. Sebagai contoh, peristiwa pemboman Nagasaki dan Hiroshima di Jepang oleh tentara sekutu' pada 1942 telah membuktikan terjadinya kerusakan lingkungan akibat radiasi bom atom dan juga memakan korban manusia yang cukup banyak, namun demikian sampai saat ini perang masih diakui sebagai salah satu mekanisme penyelesaian sengketa dalam hukum internasional. ${ }^{2}$

Dalam keadaan perang terbuka baik itu perang antar negara maupun perang untuk mempertahankan keutuhan wilayah suatu negara, seperti di Indonesia yaitu diberlakukannya Darurat Militer di Nangroe Aceh Darussalam (NAD) bentrokan bersenjata tidak dapat dihindari antara Gerakan Aceh Merdeka (GAM) dan TNI. Dalam konflik bersenjata antara TNI dan GAM perlindungan lingkungan tidak diperhatikan, bahkan hukum perang tidak dihiraukan oleh GAM. Kelompok GAM melakukan perusakan terhadap fasilitasfasilitas umum yang dilarang dalam hukum perang, sehingga penduduk sipil banyak yang

'Michael Akehurst, A Modem Introduction of Intemational Law, Fourth Edition, (London: George Aller and Unwin Publisherrs, 1982), him. 232-233.

2 J.G. Starke, Pengantar Hukum Iniemasionao, Buku 2 Edisi Kesepulth, (Jakarta: Sinar Grafika, 1992), him. 679. 
menderita akibat uiah GAM. GAM tidak saja membumihanguskan sekolah-sekolah tetapi juga telah merusak instalasi-instalasi listrik. Dampak dari akibat semua itu di antaranya kehilangan anggota keluarga yang dicintai, kehilangan harta benda dan kehilangan pekerjaan, serta keadaan yang selalu terancam mara bahaya.

Perlindungan lingkungan tidak diatur secara eksplisit dalam hukum hak asasi manusia maupun hukum humaniter. Namun demikian, mengingat hak untuk menikmati lingkungan yang sehat sudah diakui dalam hukum fingkungan intemasional,maka hak ini seharusnya juga tetap dilindungi sekalipun pada waktu perang. Pada 1968 Majelis Umum PBB pertama kali mengakui hubungan antara kualitas lingkungan dan pemenuhan hak-hak fundamental dari hak asasi manusia. ${ }^{3}$ Deklarasi Stockholm menyatakan bahwa lingkungan alam dan lingkungan buatan manusia, merupakan suatu unsur penting untuk menikmati hak-hak fundamental tersebut, bahkan hak untuk hidup itu sendiri, sebagaimana yang termuat dalam Deklarasi Stockholm Principle 1 menyatakan:

"Man has the fundamental right to freedom, equality and adequate conditions of life, in an environment of duality that permits a life of dignity and well being, and he bears a solemn responsibility to protect and improve the environment for present and future generations. In this respect, policies promoling or perpetuating apartheid, racial segregation, discrimination, colonial and other forms of oppression and foreign domination stand condemned and must be eliminăted".

Dalam Deklarasi Stockholm bahkan ada tanggung jawab untuk melindungi lingkungan bagi kepentingan generasi yang akan datang. Oleh karena itu, dalam keadaan perang perlindungan lingkungan harus tetap dilaksanakan.

Tulisan ini akan mengkaji, bagaimanakah dampak negatif perang terhadap lingkungan? Bagaimanakah hukum hak asasi manusia dan hukum humaniter telah memberikan perlindungan lingkungan pada waktu terjadinya perang?

\section{Dampak Negatif Perang terhadap Lingkungan}

Aktivitas militer memiliki dampak yang signifikan terhadap lingkungan. Percobaan, pembuatan, pemeliharaan dan penggunaarı dalam perang senjata-senjata konvensional, senjata kimia, biologi maupun senjata nuklir telah menyebabkan racun yang berbahaya (hazardous toxic) dan zat radioaktif (radioactive substances). Limbah dari kegiatan tersebut telah memberikan kontribusi pada kerusakan dan pencemaran lingkungan.

Perang sejak awal sejarahnya tidak pernah bersahabat dengan kebahagian, ketentraman dan keamanan umat manusia. Selain itu perang juga mengakibatkan pencemaran dan kerusakan lingkungan. Dalam keadaan perang terbuka sekalipun sudah diatur oleh

${ }^{3}$ Philippe Sand, Principles of intemational Law / frameworks, Standards and Implementafion, (Manchester: Manchester University Press, 1995), hlm. 222.

' Deklarasi Stockholm 1972. 
hukum internasional seperti yang tertuang dalam Konvensi Genewa 1949 tentang the Protection of Sick and Wounded Soldiers, of Sick and Wounded Sailors, of Prisoners of War and Civilians" yang kemudian pada Tahun 1977 telah dibentuk Protokol sebagai supplemen dalam kenyataannya sering terjadi pelanggaran, sehingga tidak sedikit objekobjek sipil maupun orang-orang sipil menjadi sasaran penyerangan.

Larangan penyerangan terhadap orangorang sipil dan objek-objek tersebut dalam rangka untuk melindungi infrasrtuktur, sumbersumber alam yang dibutuhkan untuk mempertahankan kesehatan manusia dan lingkungannya. Larangan untuk menyerang sumber-sumber makanan dan air adalah untuk mencegah terjadinya kekurangan nutrisi dan menghindari tercemarnya sumber air dengan dilakukannya penyerangan terhadap sistem perairan. ${ }^{5}$ Baik malnutrition maupun air yang terkontaminasi (tercemar) merupakan penyebab terjadinya ancaman terhadap jistem ke!.ebalan manusia. Berdasarkan penelitian yang dilakukan oleh Komite Palang Merah Internasional bahwa kematian di daerah pengungsiaan $50 \%$ disebabkan oleh terjadinya pencemaran air (air yang telah terkontaminasi). ${ }^{6}$ Hal ini misalnya terjadi pada pengungsi Rwanda di Zaire, dimana hampir 50.000 pengungsi meninggal karena penyakit Cholera pada bulan pertama di Kamp pengungsi tersebut?
Sayangnya, peraturan yang melindungi penduduk sipil pada umumnya seringkali dilanggar baik dalam perang antar negara maupun dalam civil war. Secara umum penduduk sipil telah dijadikan sasaran dalam perang, hal ini sangat bertentangan dengan hukum humaniter. Konflik yang terjadi di Bosnia misalnya menyebabkan penduduk sipil dalam penderitaan selama berlangsungnya konflik bersenjata. Kemudian, pada waktu Iraq menduduki Kuwait, Iraq telah menghancurkan sistem perairan di Kuwait, sedangkan pada waktu terjadinya civil war di former Yugoslavia telah menghancurkan sistem perairan dan juga sistem sanitasi. The Intemational Committee of the Red Cross melaporkan bahwa masalah yang serius dihadapidan menyebabkan wabah penyakit adalah diserangnya sistem perairan pada waktu perang. Kematian justru lebih banyak terjadi disebabkan oleh wabah penyakit menular daripada yang mati karena terkena senjata langsung. ${ }^{\text {K Kemudian, pada }}$ Maret 2003 terjadi serangan Amerika dan sekutunya ke Iraq telah menghancurkan fasilitas umum seperti instalasi listrik, jembatan-jembatan dan jalan-jalan sehingga hal ini juga menyebabkan penderitaan kepada penduduk sipil dan pencemaran air di KampKamp pengungsian. Di Indonesia yang sekarang ini masih berlangsung yaitu diberlakukannya Darurat Militer di Propinsi Nangroe Aceh Darussalam telah terjadi penyerangan terhadap fasilitas umum.

${ }^{5}$ Dafid P. Fidler, Intemational Law and Public Health: Materials on and Analysis of Global Health Jurisprudence (New York: Transnational Publishers Inc, 2000), him. 376.

${ }^{6} \mathrm{lbid}$.

${ }^{7}$ David P Fidler, Intemational Law and Infectious Diseases (New York: Oxford University Press, 1999), hlm. 234.

Ibid. 
Pemberlakuan Darurat militer di Propinsi Nangroe Aceh Darusalam (NAD) telah menimbulkan banyak kerusakan fasilitas umum berupa pembakaran sekolah-sekolah yang berjumlah kurang lebih 500 unit yang dilakukan oleh kelompok GAM, beserta telah dirusaknya instalasi-instalasi listrik yang telah menyebabkan aliran listrik di wilayah tertentu menjadi padam. Selain itu banyak warga yang mengungsi dan terkena wabah penyakit di Kamp-Kamp pengungsian.

Sekalipun dałam hukum Humaniter sudah dilarang adanya penyerangan terhadap fasilitas umum dan penduduk sipil, tetapi dalam kenyataannya apabila konflik bersenjata sedang berlangsung apa yang termuat dalam konvensi atau protokol itu seolah-olah hanyalah suatu slogan yang menjanjikan suatu keamanan, akan tetapi kenyataannya tetap saja terjadi penyerangan terhadap fasilitasfasilitas umum seperti instalasi listrik, instalasi air dan saran-sarana publik lainnya bahkan harta milik warga sipil menjadi korban. Dengan demikian dampak negatif perang terhadap lingkungan hidup antara lain dapat diklasifikasi akan dalam dua klasifikasi yaitu dampak terhadap lingkungan alami (natural environment) dan dampak lingkungan sosial (social environment). ${ }^{9}$ Adapun perincian lebih lanjut dampak perang terhadap lingkungan sosial maupun lingkungan hidup secara umum antara lain ialah: (a). Penyerangan terhadap tempat tinggal penduduk; (b). Penyerangan terhadap fasilitas umum seperti instalasi listrik;instalasi air, jembatan, dan sekolahsekolah yang dibumi hanguskan; (c). Macètnya kegiatan perekonomian; dan (d). Terjangkitnya wabah penyakit di tempat-tempat pengungsian.

Fakta-fakta tersebut menunjukkan dampak negatif yang terjadi akibat perang terbuka baik itu perang antar negara maupun perang yang terjadi karena mempertahankan keutuhan wilayah seperti kasus Operasi Militer di NAD.

Perang telah menyebabkan ancaman keamanan kepada penduduk sipil, sehingga mereka pindah ke daerah yang lebih aman untuk mengungsi. Di pengungsian inilah penderitaan baru dimulai yang tidak pernah terbayangkan sebelumnya.

\section{Hubungan antara Hak Asasi Manusia dan Perlindungan Lingkungan}

Manusia adalah bagian dari ekosistem, manusia juga sebagai pengelola dari sistem tersebut. Kerusakan dan pencemaran lingkungan baik yang dilakukan pada waktu damai maupun pada waktu perang adalah pengaruh sampingan dari tindakan manusia untuk mencapai suatu tujuan yang mempunyai konsekuensi terhadap lingkungan.10

Jika hanya diperhatikan secara sepintas, memang belum begitu jelas hubungan hak asasi manusia dan perlindungan lingkungan. Namun demikian untuk mengetahui bagaimana hubungan antarahak asasi manusia dan perindungan lingkungan dapat

${ }^{8}$ Daud Silalahi, Hukum Lingkungan Dalam Sistem Penegakan Hukum Lingkungan Indonesia (Bandung: Alumni, 1992), hlm. 9.

${ }^{10}$ Koesnadi Hardjasoemantri, Hukum Tała Lingkungan, Edisi Kelujuh, (Yogyakarta: Gadjah Mada University Press, 1999), hlm.4. 
ditelusuri dalan) dua hal, pertama perlindungan lingkungan dapat dipergunakan sebagai alat untuk memenuhi standar hak asasi manusia untuk menikmati lingkungan yang sehat, karena perusakan dan pencemaran lingkungan merupakan pelanggaran terhadap hak untuk hidup sehat, yang berarti pelanggaran hak asasi manusia yang telah diakui dalam hukum internasional. Selain itu, pelaksanaan sistem perlindungan lingkungan yang efektif akan menjamin kelangsungan sumber-sumber alam untuk generasi yang akan datang."

Kedua, perlindungan hak asasi manusia merupakan suatu cara yang efektif untuk perlindungan lingkungan, sehingga perwujudan perlindungan lingkungan untuk generasi sekarang dan generasi yang akan datang dapat terwujud. Dengan demikian dibutuhkan peraturan hukum untuk melindungi hak untuk hidup sehat Pertanyaan yang muncul ialah mengapa dilakukan pendekatan hak asasi manusia untuk perlindungan lingkungan? Karena kalau dikaitkan antara jerlindungan lingkungan dengan hak hidup yang merupakan hak asasi manusia sangat erat kaitannya, supaya fungsi lingkungan dapat berkelanjutan. Oleh karena itu, kalau terjadi pelanggaran perlindungan lingkungan juga merupakan pelanggaran terhadap hak asasi manusia. Hak untuk hidup hanya akan tercapai kalau lingkungan tetap dalam keadaan sehat terhindar dari pencemaran dan kerusakan. Dengan demikian, penegakan hak lingkungan akan sangat mendukung penegakan hak asasi manusia. Selain itu, dapat dikatakan juga bahwa perlindungan hak untuk hidup pada waktu perang yang diatur dalam hukum humaniter se':ara tidak langsung juga merupakan perlindungan terhadap lingkungan.

\section{Hubungan antara Hak Asasi Manusia dan Perlindungan Lingkungan}

Pertanyaan yang yang muncul ialah mengapa dalam kontek perang perlindungan lingkungan dikaitkan dengan perlindungan hak asasi manusia? Apakah karena konsep hak asasi manusia sudah diakui dalam masyarakat internasional, sehingga perluasan konsep hak asasi manusia yang meliputi juga perlindungan lingkungan akan lebih bermakna.

Alasan mengapa perlindungaṇ lingkungan dikaitkan dengan hak asasi manusia manusia ialah supaya hak lingkungan ini memiliki derajat yang sama dengan hak untuk ekonomi dan hak sosial dan mengakui bahwa lingkungan yang sehat merupakan kondisi dasar untuk hidup yang sehat, dan dalam hal ini berati juga pemenuhan terhadap hak asasi manusia lainnya. Sebagaimana argumen yang dikemukakan oleh Pathak sebagai berikut:

"... the protection and improvement of man's environment arise directly out of a vital need to protect human life to assure its quality and condition, to ensure the prerequisites indispensable to safeguarding human worth and the development of the human personality, and to create an ethos promoting individual and collective welfare in all the dimensions of human existence. ${ }^{112}$

"Alan E. Boyle and Michael R. Anderson (ed), Human Rights Approaches to Environmental Protection, (New York: Oxford University Press, 1996), hlm. 3.

${ }_{12}$ Pathak, dalam Edith Brown Weiss (ed), Environmental Change and Intemational Law, h/m.205-209. Sebagaimana dikutip oleh, Alan E Boyle and Michael Anderson (ed), op.cit. him. 49. 
Dalam argumen Pathak ini dapat disimpulkan bahwa ada ketergantungan antara hak asasi dengan perlindungan lingkungan , khususnya hak untuk hidup sehat.

Hak asasi yang termuat dalam Deklarasi Hak Asasi Manusia 1948 (The Universal Declaration of Human Rights) ${ }^{13}$ dapat diperluas penafsirannya untuk mencakup pertindungan lingkungan. Hal ini merupakan suatu cara untuk melindungi lingkungan berdasarkan hak asasi manusia yang telah. diakui keberadaannya. Pembentukan standar hak asasi manusia yang tidak secara langsung mengatur masalah lingkungan dapat ditafsirkan secara luas. Misalnya, hak untuk hidup dapat dikatakan dilanggar jika negara gagal untuk mencegah pencemaran yang serius pada persediaan air minum. Jika lembaga penegak hukum memahami hubungan hak asasi manusia dengan lingkungan, maka perlindungan lingkungan dapat dilakukan bersama-sama dengan perlindungan hak asasi manusia. Di India misalnya, hak untuk hidup penafsirannya telah diperluas termasuk hak untuk menikmati lingkungan yang sehat, bebas dari pencemaran dan kerusakan serta terdapat keseimbangan ekologi yang dilindungi oleh n़egara. ${ }^{14}$
Hak asasi lainnya yang juga dapat ditafsirkankan secara luas antara lain, pertama hak kesamaan (equality) dapat ditafsirkan termasuk hak yang sama untuk akses terhadap lingkungan yang sehat dan terhadap sumbersumber alam. Kedua, hak untuk berbicara dapat ditafsirkan adanya keberanian untuk mengemukakan pendapat berkeberatan atas kerusakan dan pèncemaran lingkungan. Ketiga, hak terhadap harta kekayaan dapat ditafsirkan bahwa kekayaan yang dimilikinya harus bebas dari pencemaran, ha! ini juga dapat dipergunakan untuk perlindungan lingkungan, meskipun berkaitan dengan perlindungan hak ekonomi dan hak politik. ${ }^{15}$

Akan tetapi hal yang lebih penting, ialah masalah penegakan hak asasi manusia dan perlindungan lingkungan secara efektif. Tidak ada suatu alasan yang melandasi, mengapa hak lingkungan tidak dapat ditegakkan bersamaan dengan hak-hak asasi manusia lainnya pada tingkat internasional? Misal hak untuk melakukan analisis mengenai dampak lingkungan dapat dengan mudah dilaksanakan sebagaimana hak berpolitik, sementara hak terhadap lingkungan yang sehat dapat dengan mudah diimplementasikan melalui perluasan penafsiran hak untuk hidup sehat. Dalam hukum hak asasi manusia internasional

\footnotetext{
${ }^{13}$ Lung-chu Chen, An Introduction to Contemporary International Law, (London: Yale University Press, 1989, him. 207.

"Alan Boyle and Michael Anderson (ed), op.cit. him. 7.

${ }^{15}$ Martin Dixon MA, International Law, Fourth Edition, (London: Blackstone Press Limited, 2000), hlm. 331 332. Beliau menyatakan: "Hak politik dan ekonomi ini termuat dalam The Intemational Covenant on Civil and Political Rights 1966, Covenant ini tidak sama dengan deklarasi, karena covenan mengikat secara hukum sedangkan deklarasi tidak mengikat secara hukum, sehingga bagi negara-negara yang telah meratifikasi maka terikat untuk melaksanakan ketentuan-ketentuan yang termuat dalam Covenan ini."
} 
terdapat mekanisme prosedural yang tersedia untuk diimplementasikan. Hal tersebut meliputi: prosedur pelaporan, badan penemuan fakta, prosedứ pengaduan, penyelesaian sengketa secara yuridis dan penyelesaian sengketa nonyuridis. Jika hal tersebut diterapkan dalam perlindungan lingkungan, akan terdapat suatu keharmonisan, misal dalam prosedur pelaporan hal ini dapat juga dilaksanakan oleh negara dalam laporan mengenai kondisi lingkungan dan kebijakan lingkungan.

Hubungan antara hak asasi manusia dan hak atas lingkungan yang sehat merupakan hak solidaritas atau hak generasi ketiga ${ }^{16}$ bersama-sama dengan hak perdamaian, dan hak untuk melakukan pembangunan. ${ }^{17}$ Dalam kaitan pelaksanaan hak hidup yang sehat dengan hak lingkungan yang sehat harus dipandang dalam kontek kewajiban terhadap generasi yang akan datang. Kewajiban ini dinyatakan dalam prinsip "intergenerational equity." Menurut Edith Brown Weiss prinsip intergenerational equity meliputi tiga hal sebagai berikut:

"First each generation should be required to consenve the diversity of the natural and cultural resource base, so that it does not unduly restrict the option available to future generations to solving their problems and satisfying their own values, and also be entitled to diversity comparable to that enjoyed by previous generation. This Principle is called "conservation of options." Second, each should be required to maintain the quality of the planet so that it is passed in no worse condition than that in which it was received, and should also be entifled to planetary quality comparable to that enjoyed by previous generations. This is the Principle of "conservation of quality." Third, each generation should provide its members with equitable rights of access to the legacy of past generations and should conserve this access for future generations. This is the Principle of "conservation of access. ${ }^{\text {"18 }}$

Dari prinsip-prinsip tersebut dapat dipahami bahwa prinsip pilihan konservasi (conservation of options) mensyaratkan adanya keseimbangan antar generasi dalam memilih alternatif pengelolaan keanekaragaman sumber alam dan budaya. Prinsip konservasi kualitas (conservation of quality) mensyaratkan adanya keseimbangan

${ }^{18}$ Alan Boyle, "The Role of International Human Rights Law in the Protection of the Environment", dalam Alan Boyle and Michael Anderson (ed), op.cit. hlm. 46. Beliau menyatakan: "Hak solidaritas atau hak generasi ketiga ialah suatu hak yang lebih banyak dinikmati dalam suatu kelompok dari pada secara individu. Dalam pelaksanaan hak ini membutuhkan kerjasama pemerintah dan badan-badan internasional untuk membantu pelaksanaan hak tersebut mengingat keterbatasan sumber-sumber alam yang tersedia. Hak ini mengandung unsur-unsur redistribusi keadilan."

"Boer Mauna, Hukum Intemasional Pengertian Peranan dan Fungsi dalam Era Dinamika Global, (Bandung: Alumni, 2000), him. 595.

${ }^{18}$ Edith Brown Weiss, "Intergenerational Equity: A Legal Framework for Global Environmental Change," alam Edith Brown Weiss (ed), Environmental Change and Intemational Law New Challenges and Dimensions (Tokyo: United Nations University Press, 1992), hlm. 401. 
antar generasi dalam memilih alternatif pengelolaan keanekaragaman sumber alam dan budaya. Prinsip konservasi akses (conservation of access) mensyaratkan adanya kesempatan yang sama untuk akses terhadap sumber alam dan budaya sebagaimana yang dinikmati oleh generasi yang sekarang. Kalau ditelaah lebih lanjut ternyata bahwa pemberian jaminan atas generasi yang akan datang ini juga harus berdasarkan prinsip-prinsip keadilan memiliki hak yang sama dengan generasi yang sekarang untuk menikmati lingkungan yang sama. ${ }^{19}$ Hak untuk menikmati lingkungan yang sehat sebagaimana yang tertuang dalam Deklarasi Stockholm tidak mengikat secara hukum (non-legally binding), akan tetapi selain deklarasi ini ada ketentuan lain yang memuat hak untuk menikmati lingkungan hidup yang sehat yang termuat dalam The Word Charter for Nature 1982. The Word Charter for Nature merupakan salah satu instrumen pertama yang mengakui hak individu untuk berpartisipasi dalam pengambilan keputusan dan memiliki akses untuk memperoleh kompensasi jika mengalami penderitaan akibat kerusakan lingkungan.20

Peranan apa yang seharusnya diberikan oleh hukum hak asasi manusia terhadap perlindungan lingkungan? Pada waktu diselenggarakannya Konferensi Stockholm 1972 Konferensi PBB tentang lingkungan dan manusia menyatakan: "Man has the fundamental right to freedom, equality and adequqte conditions of life in an environtment of a qual- ity that permits a life of dignity and well. being." Dua puluh tahun kemudian, pada waktu Konferensi Rio tentang Lingkungan dan Pembangunan, cikal bakal tentang hak asasi manusia tidak dipelihara. Menghindari terminologi hak secara bersama-sama, Deklarasi Rio hanya menyebutkan "Human beings are at the center of concems for sustainable development. They are entitled to healthy and productive life in harmony with nature."

Deklarasi Rio telah gagal untuk menekankan hak asasi manusia dalam bidang lingkungan sebagai bagian dari hukum hak asasi manusia dalam perkembangan hukum lingkungąn internasional. Hal ini bukan karena disebabkan oleh kurangnya kepentingan pada masalah ini. Akan tetapi sebaliknya, referensi tentang hak terhadap kesehatan, atau hak lain yang berkaitan dengan lingkungan muncul dalam beberapa konvensi hak asasi manusia baik global maupun regional, dan dalam resolusi organisasi internasional.

Secara jelas dinyatakan dalam Deklarasi Rio tentang hak lingkungan dalam bentuk claim lingkungan sebagai warisan untuk memperoleh kesehatan manfaatnya. Dalam hal ini hak lingkungan menuntut adanya suatu tingkat kualitas lingkungan tertentu. Selain itu, hak lingkungan juga termuat dalam Draft Principles of the UN Sub-Commission on Human Rights and Environment yang meliputi: (1). Kebebasan dari polusi, kerusakan lingkungan, kegiatan yang membahayakan terhadap lingkungan, atau mengancam kehidupan,

${ }^{18}$ R.S, Pathak, "The Human Rights System as A Conceptual Framework for Environmental Law", dalam Edith Brown Weiss, op.crt. hlm. 226.

${ }^{20}$ Philippe Sand, supra note 3. 
kesehatan atau pembangunan berkelanjutan; (2). Perlindungan dan pelestarian terhadap udara, tanah, air, daerah kutup, flora dan fauna, serta proses yang penting untuk pelestarian keanekaragaman hayati dan ekosistem; (3). Standar yang tinggi untuk kesehatan; (4). Makanan, air dan lingkungan kerja yang sehat; (5). Perumahan yang memadahi dan kondisi kehidupan yang aman serta berwawasan lingkungan; (6). Akses terhadap ekologi, dan konservasi sumber daya alam yang berkelanjutan; (7). Pelestarian tempat-tempat yang unik; (8). Hak untuk menikmati kehidupan tradisional. ${ }^{21}$ Hak-hak tersebut menggambarkan adanya hubungan yang erat antara perlindungan hak asasi manusia dan perindungan lingkungan.

Beberapa usaha telah dilakukan oleh institusi hak asasi manusia, dan oleh para penulis, untuk menarik atau menjadikan hak lingkungan sebagai bagian dari hak asasi hak-hak lain yang dilindungi oleh hukum internasional. Selain itu ada suatu kecenderungan baru untuk menempatkan perlindungan lingkungan dalam konstitusional nasional suatu negara baik secara eksplisit maupun secara implisit dalam perundangundangan lainnya. Hal ini telah mendorong UN - Sub Commission on the Prevention of Discrimination and Protection of Minorities untuk mengadakan suatu studi tentang hak asasi manusia dan lingkungan untuk mengetahui dimana posisi hukum hak asasi manusia dalam periindungan lingkungan.

Lebih lanjut lagi, hal yang sangat penting adalah memperoleh poin-poin tentang sifat human rights dan perlindungannya dalam hukum internasional. Khususnya, perbedaan hak sipil dan politik serta hak ekonomi dan hak sosial, yang sering disebut hak solidaritas atau hak generasi ketiga memeiliki implikasi yang penting dalam pengembangan hak lingkungan sebagai bagian dari hak asasi manusia. Perbedaan diantara hak-hak tersebut belumlah begitu jelas, namun secara pragmatis sudah tertuang dalam UN Covenants 1966 tentang Civil and Political Rights and Economic, Sosial and Cultural Rights.

Civil and Political rights diklasifikasikan sebagai hak individu yang kurang dari pengaruh campur tangan pemerintah ${ }^{2}$ dalam masyarakat sipil, sedangkan hak sosial dan ekonomi biasanya ada campur tangan pemerintah dalam bentuk kebijaksanaan yang menciptakan kondisi bagi individu atau kelompok tertentu untuk menciptakan keseimbangan diantara mereka. Sedangkan hak generasi ketiga atau hak solidaritas meliputi perdamaian, pembangunan dan lingkungan yang baik, yang biasanya diperoleh dalam kelompok daripada secara individual. Pemenuhan hak ini membutuhkan kerjasama dengan pemerintah maupun agen-agen internasional untuk. bekerjasama dan membantu untuk membantu kelompokkelompok tersebut dalam memenuhi kebutuhannya dengan sumber alam yang terbatas. Isi daripada hak solidaritas masih sangat programatik, akan tetapi pertanggungjawabannya tersebar dan berisi keadilan distributif antar negara.

\footnotetext{
${ }^{21}$ Alan E. Boyle and Michael R. Anderson, op.cit. hlm. 48.

${ }^{22}$ Alan E. Boyle and Michael R. Anderson (ed), op.cil, hlm.46.
} 


\section{Perïndungan Lingkungan dalam Hukum Humaniter}

Dalam hukum humaniter memang tidak secara langsung mengatur mengenai perlindungan lingkungan, akan tetapi kalau dipelajari secara cermat maka akan ditemukan suatu ketentuan yang implisit tentang perlindungan lingkungan pada waktu perang. Hukum Humaniter yang termuat dalam Perjanjian Internasional dan hukum kebiasaan internasional telah dikembangkan untuk melindungi manusia dan harta bendanya, dan secara tidak langsung juga bertujuan untuk melindungi lingkungan. Perang yang telah mengakibatkan pencemaran air bersih, pencemaran udara dan hilangnya daerah pemukiman telah memberikan kontribusi yang besar terhadap kerusakan lingkungan. Oleh karena itu, pelaksanaan dari ketentuan tersebut harus dipertegas dan dilaksanakan dengan penuh tanggung jawab.

Lalu bagaimana perlindungan lingkungan yang diatur dalam hukum lingkungan internasional? Ternyata Hukum Internasional hanya memberikan sedikit pedoman mengenai validitas suatu perjanjian internasional dalam keadan perang. ${ }^{23}$ Kevalidan dan akibat suatu perjanjian internasional pada waktu perang atau konflik bersenjata akan tergantung pada ketentuan perjanjian itu sendiri. Instrumen dalam Hukum Lingkungan internasiona! memberikan suatu pedoman tentang berlakunya perjanjian internasional atau deklarasi pada wakłu perang. Misalnya saja, dalam Deklarasi Stockholm Principle 26 menyatakan:

"Man and his environment must be spared the effects of nuclear weapons and all other means of mass detruction. States must strive to reach promt agreement, in the relevant intermational organs, on the elimination and complete destruction of such weapons."

Adapun The Word Charter for Nature mengadopsi pendekatan yang bersifat lebih umum, dengan menyatakan bahwa alam harus diselamatkan dari kerusakan yang disebabkan oleh perang atau aktivitas-aktivitas militer lainnya yang merusakkan lingkungan harus dihindari. ${ }^{24}$ Lebih lanjut lagi dalam Deklarasi kio juga mengatur perlindungan lingkungan pada waktu perang sebagaimana yang tertuang pada Principle 24 sebagai berikut:

"Warfare is inherently destructive of sustainable development. States shall therefore respect international law providing protection for the environment in time of arm conflict and co-operate in its further development, as necessary."

Walaupun ketentuan yang dimuat dalam Deklarasi Rio ini tidaklah mengikat secara hukum, namun kata-kata yang tercantum dalam Principle 24 ini dapat ditafsirkan bahwa ketentuan ini memerintahkan pada negaranegara anggota untuk menghormati ketentuanketentuan dalam hukum internasional yang mengatur perlindungan lingkungan pada waktu perang atau konflik bersenjata.

\footnotetext{
${ }^{23}$ Art. 73 of the 1969 Vienna Convention: "the present Convention shall not preiudge any question that may arise in regard to a treaty from ... the outbreak of hostifities between State".

${ }^{24}$ Philippe Sand. Intemalional Law and Infecfious Deseases, op.cit. him.231-232.
} 
Misalnya saja, dalam peraturan umum hukum internasional menentukan metode dan peralatan perang tidak tak terbatas. Berarti, metode dan peralatan perang yang dipergunakan hanya terbatas pada metode dan peralatan yang dibutuhkan untuk objekobjek militer. Hal ini untuk mencegah korbankorban dan kerusakan lingkungan yang tidak diinginkan. Sejak permulaan 1899 telah diterima suatu peraturan bahwa belligeren telah menerima ketentuan penggunaan senjata yang terbatas. Kemudian pada 1977 Protokol Tambahan I menyatakan bahwa dalam setiap konflik bersenjata, hak dari para pihak untuk menggunakan metode dan macam persenjataan tidak tak terbatas. Sebagai aturan umum ialah perusakan terhadap harta kekayaan dilarang kecuali kekayaan tersebut dipergunakan untuk membantu kepentingan militer.

Kewajiban umum yang membatasi metode dan cara perang telah ditambah dengan perjanjian internasional khusus yang berisi kewajiban-kewajiban yang melarang bentuk senjata tertentu yang menyebabkan kerusakan lingkungan. Misalnya, Geneva Protocol of 1925 Prohibited the Use of Gas and Bacteriological Warfare. Walaupun ketentuanketentuan tersebut terutama ditujukan untuk perlindungan manusia, akan tetapi secara tidak langsung juga untuk melindungi lingkungan. Dalam konvensi yang lain mengatur mengenai pelarangan penggunaan senjata konvensional yang menyebabkan luka yang beriebihan ${ }^{25}$ termasuk senjata biologi, senjata kimia, serta senjata nuklir.
Hukum Humaniter yang berisi peraturan fundamental menyatakan bahwa Angkatan Bersenjata hanya diizinkan untuk menyerang militer dan tidak diperkenankan menyerang orang-orang sipil. Peraturan yang bersifat umum ini dilengkapi dengan peraturan khusus yang berkaitan dengan penyakit menular. Sebagai contoh, penyerangan dilarang dilakukan terhadap objek-objek penting yang berkaitan dengan keselamatan orang-orang sipil seperti bahan-bahan makanan, tanaman, ternak, instalasi air minum serta aliran air untuk ingasi juga dilarang. Bahkan jika objek-objek ini dipergunakan untuk mensuplai angkatan bersenjata, sumber-sumber tersebut tidak akan diserang jika akibatnya akan menyebabkan penduduk sipil kekurangan air minum atau kekurangan bahan makanan dan menyebabkan mereka dalam kesengsaraan.

Perlindungan lingkungan yang lebih spesifik adalah larangan penyerangan terhadap instalasi yang merupakan kepentingan umum seperti instalasi listrik dan air, bahkan jika hal tersebut merupakan benda milik militer, tetapi kalau penyerangan tersebut dilakukan akan menyebabkan kerugian kepada orang-orang sipil atau dapat menyebabkan korban orang-orang sipil atau melukai atau merusak harta benda dikatagorikan sebagai tindakan kriminal.The International Atomic Energy Agency (IAIA) melarang penyerangan terhadap fasilitas nuklir karena hal ini dapat menyebabkan radiasi yang sangat berbahaya bagi manusia dan mencemarkan lingkungan. Selain itu international Law Association (ILA) telah

${ }^{25}$ Lihat, Convention on Prohibitions or Restriction on the Use of Certain Conventional Weapons 1981. 
menyatakan adanya larangan untuk menyerang instalasi air, yang mungkin saja mempengaruhi keseimbangan ekologi, sedangkan dalam The Draft Code of Crime against the Peace and Security of Mankind menyatakan bahwa penggunaan cara dan peralatan perang yang ditujukan untuk menyebabkan kerusakan lingkungan adalah merupakan tindakan kriminal yang serius.

Pada Mei 1993 the Assembly of the WHO mengadopsi sebuah resolusi yang meminta kepada Mahkamah Internasional untuk menangani atau memberikan suatu nasehat tentang persoalan sebagai berikut: "Untuk kepentingan kesehatan dan akibatnya terhadap lingkungan, apakah penggunaan senjata nuklir oleh suatu negara dalam peperangan atau konflik bersenjata merupakan pelanggaran terhadap hukum internasional termasuk konstitusi WHO?

Perjanjian Internasional pertama yang mengatur secara khusus perlindungan lingkungan sebagai konsekuensi kegiatan militer ialah Convention on the Prohibition of Military or Any other Hostile Use of Environmental Modification Techniques (ENMOD Convention 1977). Konvensi ini melarang para pihak dalam konflik bersenjata untuk menggunakan cara-cara dan persenjataan serta teknik-teknik modifikasi lingkungan yang bertujuan untuk menimbulkan kerusakan atau luka-luka atau penderitaan yang mendalam kepada pihak lain. Konvensi ini mendefinisikan "environmental modification techniques: as any technique for changing - through the deleberate manipulation of natural processesthe dynamics composition or structure of the Earth, including its biota, lithosphere, hydrosphere and atmosphere, or of outer space."

Beberapa bulan setelah ENMOD Conven- tion dilaksanakan, maka pada 1977 telah dikeluarkan Protokol Tambahan I terhadap Konvensi Genewa 1949 tentang The Conventions Relating to the Victims of Armed Conflict telah diadopsi. pada 1977 Protokol Tambahan berisi dua kewajiban ekplisit yang direncanakan untuk melindungi lingkungan. Berdasarkan article 35 melarang untuk menggunakan cara dan peralatan perang yang dimaksudkan atau diharapkan menyebabkan kerusakan yang meluas dan dalam jangka panjang serta kerusakan yang serius terhadap lingkungan. Sedangkan dalam article 55 yang berjudul Perlindungan Lingkungan Alam (Protection of the Natural Environment) menyatakan:

"Care shall be faken in warfare to protect the natural environment against widespread, long-term and severe damage. This protection include a prohibition of the - use of methods ormeans of warfare which are intended or may be expected to cause such damage to the natural environment and thereby to prejudice the health or survival of the population "

Protokol ini juga melarang perusakan lingkungan alam dengan alasan pembalasan (reprisals).

Kewajiban perlindungan lingkungan yang paling ketat tidak berasal dari-suatu konvensi, tetapi berasal dari resolusi Dewan Keamanan. Pada waktu Iraq menginvasi Kuwait bulan Agustus 1990, resolusi ini mewajibkan pertanggung jawaban negara atas invasi militer yang dilakukan oleh Iraq. Resolusi No. 687 menguatkan bahwa Iraq berdasarkan hukum internasional bertanggung jawab terhadap kerusakan lingkungan dan kerusakan sumber-sumber alam yang diakibatkan oleh invasi yang tidak sah terhadap Kuwait. 
Invasi Iraq ke Kuwait telah mengarah pada pertimbangan yang lebih jauh terhadap lingkungan sebagai akibat perang dan konflik bersenjata. Pada Desember 1992 Majelis Umum mengadopsi sebuah resolusi Majelis yang memperkuat bahwa perusakan lingkungan tidak dibenarkan berdasarkan kepentingan militer, selain itu ketentuanketentuan yang ada juga melarang perusakan terhadap sumur-sumur minyak dan membuang limbah minyak mentah ke laut. Majelis Umum PBB mendorong negaranegara untuk segera melakukan segala tindakan untuk menjamin ketaatan terhadap hukum internasional yang ada dalam perlindungan lingkungan pada waktu konflik bersenjata, dan meminta kepada Sekjen PBB untuk melapor kepada Majelis Umum tentang aktivitas yang dilakukan oleh Komite Palang Merah dan dan badan-badan lain yang relevan.

\section{Simpulan}

Perlindungan lingkungan dalam hukum hak asasi manusia maupun dalam hukum humaniter masih sangat lemah, sekalipun hak terhadap lingkungan yang sehat sudah diakui sebagai hak yang sejajar dengan hak untuk melakukañ pembangunan dan hak untuk menikmati perdamaian yang dikenal dengan hak solidaritas atau hak generasi ketiga.

Usaha-usaha yang dilakukan oleh masyarakat internasional untuk menggabungkan perlindungan hak asasi manusia dan hak lingkungan dalam hukum hak asasi manusia maupun dalam hukum humaniter perlu ditindak lanjuti dengan memberikan penafsiran secara luas hak-hak yang telah dilindungi oleh hukum hak asasi manusia maupun dalam hukum humaniter.a

\section{Daftar Pustaka}

Michael, Akehurst, A Modem Introduction of Intemational Law, Fourth Edition, London: George Allen and Unwin Publisher, 1982.

Alan, Boyle E and Michael Anderson (ed), Human Rights Approaches to Environmental Protection, New York: Oxford University Press, 1996.

Mauna, Boer, Hukum Intemasional Pengertian Peranan dan Fungsi dalam Era Dinamika Global, Bandung: Alumni, 2000.

Edith, Brown Weiss, (ed), Environmental Change and International Law New Challenges and Dimensions, Tokyo: United Nations University Press, 1992.

Lung-chu, Chen, An Introduction to Contemporary Intermational Law, , London: Yale University Press, 1989.

Convention on the Prohibition of Military or Any other Hostile Use of Environmental Modification Techniques ( ENMOD Convention 1977).

Convention on Prohibitions or Restriction on the Use of Certain Conventional Weapons Tahun 1981.

Silalahi, Daud, Hukum Lingkungan Dalam Sistem Penegakan Hukum Lingkungan Indonesia, Bandung: Alumni, 1992.

Deklarasi Stockholm 1972

Deklarasi Rio 1992 
Fidler, David P., International Law and Public Health: Materials on Analysis of Global Health Jurisprudence, New York: Transnasional Publishers. Inc., 2000. , Intemational Law and infectious Diseases, New York: Oxford University Press, 1999.

Geneva Protocol of 1925 Prohibited the Use of Gas and Bácteriological Warfare.

Hardjasoemantri, Koesnadi, Hukum Tata Lingkungan, Edisi Ketujuh, Yogyakarta: Gadjah Mada University Press, 1999.

Protokol Tambahan 1 terhadap Konvensi Genewa 1949 tentang The Conventions Relating to the Victims of Armed Conflict telah diadopsi 1977 Protokol.
Sand Philippe, Principles of Intermational Läw I frameworks, Standards and Implementation, Manchester. Manchester University Press, 1995.

Starke J.G., Pengantar Hukum Intemasionao, Buku 2 Edisi Kesepuluh, Jakarta: Sinar Grafika, 1992.

The Universal Declaration of Human Rights The Word Charter for Nature

The Draft Code of Crime against the Peace and Security of Mankind

Vienna Convention, 1949 tentang the Protection of Sick and Wounded Soldiers, of Sick and Wounded Sailors, of Prisoners of War and Civilians"

Vienna Convention 1969.

\section{DOEOEO}

